Party Finance Reform as Constitutional Engineering? The effectiveness and unintended consequences of Party Finance Reform in France and Britain

\author{
Dr. Ben Clift \\ Department of Politics and International Studies, \\ University of Warwick, \\ Coventry, \\ CV4 7AL. \\ Tel: $+44(0) 2476524547$ \\ Fax: +44 (0) 2476524221 \\ Email: B.M.Clift@Warwick.ac.uk
}

and

Dr. Justin Fisher

Department of Politics \& History

Uxbridge

Middlesex, UB8 3PH

Tel: +44 (0)1895 266309

Fax: +44 (0)1895 812595

Email: justin.fisher@brunel.ac.uk 


\title{
Party Finance Reform as Constitutional engineering? The effectiveness and unintended consequences of Party Finance Reform in France and Britain
}

\begin{abstract}
In both Britain and France, party funding was traditionally characterised by a laissez faire approach and a conspicuous lack of regulation. In France this was tantamount to a 'legislative vacuum'. In the last two decades, however, both countries have sought to fundamentally reform their political finance regulation regimes. This prompted, in Britain, the Political Parties, Elections and Referendums Act 2000, and in France a bout of 'legislative incontinence' - profoundly transforming the political finance regime between 1988 and 1995. This article seeks to explore and compare the impacts of the reforms in each country in a bid to explain the unintended consequences of the alternative paths taken and the effectiveness of the new party finance regime in each country. It finds that constitutional engineering through party finance reform is a singularly inexact science, largely due to the imperfect nature of information, the limited predictability of cause and effect, and the constraining influence of non-party actors, such as the Constitutional Council in France, and the Electoral Commission in Britain.
\end{abstract}

Keywords: France; Britain; Party funding; constitutional engineering; unintended consequences.

\section{Introduction}


Ideas about 'constitutional engineering' have been widely applied to electoral system reform (Sartori 1997; Taagepera and Shugart 1989), but much less to reforms in party funding and political finance, despite the fact that such changes profoundly affect the relative strengths and advantages of political parties. Whilst it is true that all constitutional engineering is an inexact science, it is surely particularly true in an area of democratic institutional change that has received relatively limited attention. Much work on party funding has focused on the origins of reform and the rationale underpinning reforms (see for example: Hopkin, 2004; Clift and Fisher, 2004; Scarrow, 2004; van Biezen, 2004). Whilst these are clearly important aspects of party funding, this can lead to neglect of an equally vital concern - namely the impacts of party funding reform. It is these impacts that are the focus of this article.

We analyse here on cases of France and Britain. Both are mature advanced (post-) industrial democracies, each with majoritarian party systems. Prior to party finance reforms, both had similar laissez faire traditions and unregulated arrangements for party funding. In the case of Britain, until February 2001 when the Political Parties, Elections and Referendums Act 2000 came into force, the funding regime was still shaped by the Corrupt and Illegal Practices (Prevention) Act 1883. Similarly, in France, in the first thirty years after the formation of the Fifth Republic, party funding had not been the subject of any legislative attention. Indeed, one initial hurdle to overcome in party funding reform was that parties in Britain and France were not even recognised as legal entities. As a consequence, a most similar systems design is the appropriate way to approach the comparative analysis presented here (Przeworski and Teune 1970).

This article seeks to compare the impacts and outcomes of the reform processes in each country. Having set out the analytical framework in relation to constitutional engineering, we 
establish the background to reform in both cases before comparing the initial French propositions with the British reforms, and briefly summarising the key instruments of party funding reform - donations, disclosure, campaign ceilings, and state funding. Subsequently, comparative analyses seek to explain the unintended consequences of the different paths taken and the effectiveness of party finance regulation in each country.

What emerges from our analysis is the contingent quality of the policy regime's evolution, mediated by paradigms - notably voluntarism, ${ }^{1}$ but also state funding, and in the French case the etatiste tradition. Furthermore, unintended consequences are a pervasive feature of the experiences of reform in each country. This is at least in part explicable in terms of the imperfection of the information on which reform strategies were based. Another prevalent aspect of reform is a 'strategic learning' process whereby subsequent reforms react to the impacts of earlier changes, illustrating the policy makers' roles as reflexive agents.

\section{Party Funding Reform and Constitutional Engineering}

The processes of institutional reform, in our cases, were driven by questions surrounding the ability of pre-existing institutional framework to 'deliver' appropriate political behaviour. The catalyst for change was the undermining of the legitimacy of the political finance regime, precipitating - to different degrees - political crises. Change occurred in part because rules no longer conferred legitimacy. Political behaviour was judged against (and found to be

\footnotetext{
${ }^{1}$ Voluntarism here refers to a laissez faire approach to political finance characterised by reliance upon voluntary support for political parties rather than state aid. Historically this has been accompanied by minimal state involvement and regulation. This should not be confused with (indeed it contrasts with) the French term volontarisme, referring to an activist, interventionist economic policy approach which places emphasis on the discretionary actions of state policy-makers.
} 
performing 'sub optimally' in relation to) democratic probity, fairness and transparency. In efficiency terms, both sets of funding sources and networks, it could be argued, were functional to the political system in allocating resources (though see Fisher, 2000b). However, the perceived dysfunctionality of the system had spawned a tangible gap between the internal values of the funding regime and external values of French and British democracy. The degree of perceived crisis was greater in the French case, and the scale of change more radical, yet it does not necessarily follow that the effectiveness of these changes was greater.

Perhaps the most significant theoretical exposition of constitutional engineering as applied to party finance comes in the context of Katz and Mair setting out their 'ideal type' of the Cartel Party. This thesis assumes, on the part of parties, the ability 'to manipulate the state in its own interest', specifically, by pursuing 'the provision and regulation of state subventions to political parties' (Katz and Mair 1995: 14 and 15). They continue

'precisely because these subventions are often tied to prior party performance or position, they help ensure the maintenance of existing parties while at the same time posing barriers to the emergence of new groups ... the state, which is invaded by parties, and the rules of which are determined by parties, becomes a fount of resources through which these parties not only help ensure their survival, but through which they can also enhance their capacity to resist challenges from newly mobilized alternatives. The state, in this sense, becomes becomes an institutionalized structure of support, sustaining insiders while excluding outsiders' (Katz and Mair 1995: 1516)

There are a number of underlying assumptions here which need to be unpicked for the purposes of the argument presented here. Firstly, the Katz and Mair thesis assumes a high degree of party control over the reform process, to use their phrase, an almost complete 'inter-penetration of party and state' (1995: 17). This may run the risk of under-playing the 
role of non-party actors within the state, such as, in our cases, the Electoral Commission and the Committee on Standards in Public Life in Britain, or the Constitutional Council in France.

A second assumption is the predictability of cause and effect of regarding party manipulation of regulations and subventions. As recent research shows - the effects of party funding changes are by no means uniform- and each depend on the precise nature of the instruments used, the thresholds established, and who are identified as the recipients of state support (Pierre et al 2000).

Following on from this, a third assumption is that reformers are basing their constitutional engineering through party funding regulation on something approaching perfect information. Implicit assumptions of perfect information are less than convincing in the case of party finance reform. The knowledge on which strategic calculations are based is arguably impressionistic and partial at best. This point is all the more pertinent to our substantive area - political finance reform, since it presents a non-extensively researched arena in which to attempt constitutional engineering. Care must be taken not to understate the complexity of the reform process, nor to overestimate the ability of actors to discern and achieve their goals.

Constitutional engineering through party funding reform has only a limited body of empirical evidence on which to base its blueprints, thus how groups concoct solutions, and how they are implemented may be subject to accident or error. Moreover, change cannot be controlled precisely and the long-term policy-impact of institutional changes is often unknown or highly uncertain (Thelen and Steinmo, 1992: 22). A good example in political finance terms is the Trade Union Act 1984, which required unions with political funds to engage in periodic ballots to approve the continued existence of the fund. Some saw this as a deliberate attempt 
to financially enfeeble the Labour Party. In fact, the outcome was that all unions voted to continue with political funds, and some unions adopted political funds for the first time. As a consequence, trade unions became more politicised rather than less (Fisher, 1992).

Finally, the Cartel Party thesis assumes a high degree of effectiveness of the 'cartelised' regime introduced (to ensure 'insider' parties are not really financially hurt by electoral losses, and therefore electoral 'feedback' effects are blunted). As shall be seen from the comparative analysis presented below, none of these assumptions is entirely safe in the light of the evidence from the British and French cases.

Another important consideration when assessing the impact of party finance reforms in terms of their unintended consequences is the reflexivity of the actors. Institutions constrain and shape the desires and motives of agents, but agents' 'inter-subjective' construction of structures enables them in turn to reshape institutions. Thus, 'actors are strategic, seeking to realize complex, contingent and often changing goals. They do so in a context which favours certain strategies over others and must rely on perceptions of that context which are at best incomplete and which may very often reveal themselves to be inaccurate.' (Hay and Wincott 1998: 954) Thus party funding reform involves a process of social learning. This is particularly significant in relation to the rolling programme of reform in France, where strategically selective actors shape and reshape the institutional parameters of their party finance regime as the impacts of earlier reforms become evident.

\section{Background to Reform}


The section that follows establishes the background to reform in both cases, and the rationale underpinning it. The key instruments of party funding reform in our cases - donations, disclosure, campaign ceilings, and state funding, are placed within this context.

The Rousseauian suspicion of 'intermediary' interests ('partial wills'), which represents one strand of the Republican tradition, finds expression in the Fifth Republic constitution of 1958. Although mentioned in article 4, parties' activities were completely unregulated and they were simply unrecognised in law. So powerful was the laissez faire tradition in relation to parties that, until 1988, no rules or laws existed regarding political finance. Party funding was, however, indirectly (and ineffectually) regulated by the law on abus de biens sociaux (see Table 1). Similarly, in Britain, a general lack of regulation has been a pervasive feature of British party finance. That said, campaign spending ceilings have existed since 1883, though critically, until the 2000 Act, they applied only at constituency level. They were originally designed in response to a perception that election expenditure had become excessive - concerns that were mirrored when expenditure caps were introduced at national level.

A second characteristic of French party funding flowing from this lack of regulation, and from the fact that state aids were minimal, was a reliance on voluntary income by French political parties. French parties claimed (perhaps unreliably) ${ }^{1}$ to derive most of their funding from membership dues. This reliance upon voluntary donations had also been a long running theme in British party finance, and whilst the sources of funding parties (e.g. party members, individual donors, companies, trade unions) have evolved over time, the emphasis on voluntary donations underlined the eventual reforms with the rejection of comprehensive state funding. Only the paucity of regulation has really changed in British party finance. Prior 
to the 2000 reforms, there were no limits on party income and reporting regulations were very limited.

A third tradition of French party funding also flowed from the legal vacuum, which presented an 'open door to corruption' (Miguet 1999), and was compounded by very limited state support. This was the tradition that French parties tended to be dependent upon corrupt (or as the French term them 'occult') financing networks, channelled through their local elected officials. Such practices in the French case may be contrasted with British traditions of political finance.

Part of the explanation may be derived from another significant difference. French parties are weakly embedded in civil society, with comparatively low membership levels (Knapp 2002). Claims regarding membership funding, although never true, had become decreasingly credible as costs of electoral campaigning increased in the media age, with the increased use of professionalised political marketing, advertising and public relations experts and commercial polling firms (Clift 2005: 236-8; Knapp 2002: 128). In the period before regulations formalising information gathering about party finance were introduced in 1988, evidence is accordingly limited. However, all parties used 'occult' business funding, one prevalent means was fictitious 'consultancy' work for which firms bidding for public contracts would pay parties. The PS's URBA consultancy was the most formalised and rationalised conduit for such financing, established in the early 1970s. Its discovery in 1989 led to a large number of prosecutions of politicians, both Socialists and others. ${ }^{2}$

Analysts concur that all the major parties used such funding methods (Avril 1994: 86-9; Knapp 2002: 124-5; Miguet 1998: 55; Pujas and Rhodes 1999: 43 and 52-3). Once data 
began to be collected, it became clear how limited a proportion of party finance actually came from the membership. The National Commission on Campaign Accounts and Political Finance (CNCCFP) reported in 1995 that membership subscriptions accounted for a very small proportion of parties' total income - for example PS (12 per cent) PCF (14.5 per cent) FN (10.9 per cent) (CNCCFP 1996). Such reports exposed the myth that these sources are sufficient to fund party activity in France. ${ }^{3}$

In Britain, by way of contrast, the practices, as well as the principle of voluntary donations created fewer difficulties. Following the shift form individual donations to institutional ones as a means of supporting the two main parties (the Conservatives and Labour) in the 1920s, there were no substantiated political finance scandals and a broad 'consensus' emerged whereby the principal sources of funds were companies (for the Conservatives) and trade unions (for Labour). This 'consensus' came under challenge with the re-emergence of large individual donations in the 1990s as well as the growth of smaller parties - particularly the Liberal Democrats - who had no traditional institutional base for their party income. The result, whilst not revealing any political finance scandals on the scale experienced in France, was that disquiet began to emerge regarding the probity of the voluntary system, as well as its continued ability to fund party politics adequately.

With these similarities and differences in the reform contexts in mind, we turn briefly to the rationale (and intended consequences) of party reform processes in each country.

\section{France: Rationale for Reform}

Although party finance legislation had been on the political agenda before - with 29 propositions de loi on party finance between 1970 and 1988, the political will had always 
been lacking to push through such measures (Doublet 1997: 60). The catalyst for change in the party finance regime was the scale and reach of political corruption scandals. Throughout 1987, increasing number of scandals were emerging, implicating senior members of the French Socialist elite, including former Ministers and members of Mitterrand's entourage. The impact of these scandals was reinforced by the degree of media attention afforded them. The desire to fill the legislative and regulatory 'vacuum' as a means of tackling such political corruption was compounded by tactical manoeuvring ahead of the upcoming 1988 presidential elections. In November 1987, in the wake of the Luchaire affair, ${ }^{4}$ Mitterrand called upon the Chirac government proposed to legislate to regulate party finance, both as a means of being seen to respond to tackle corruption within the Socialist camp, and to put the Gaullists on the back foot, given their own heavy reliance on such 'occult' funding sources. Raymond Barre, for this reason, also championed the call for party finance regulation. Chirac was thus somewhat manoeuvred into orchestrating the party funding reform project.

The reforms instigated, and the previous positions, are shown in Table 1 . We can identify a number of strands. Firstly, two pieces of legislation offered a fresh start in the form of an amnesty covering all prior dubious practices. The idea was to draw a 'line in the sand' under practices which, it was well known, politicians from all parties had long been engaged (as we shall see later, this was less than wholly successful). Mitterrand's post-presidential election amnesty of 1988 was followed up by a more blatant bid to save Socialist blushes when a further amnesty was written into the 1990 law with the specific intent of saving Christian Nucci from prosecution for his part in the "Carrefour du développement" scandal. Somewhat curiously, only the Communist Party objected to this, and the law was passed with the compliance of Right, illustrating what Katz and Mair term 'inter-party collusion' (1995: 
17), and an intermittent conspiracy of laxity amongst the major French parties regarding the punishment of dubious party funding.

Secondly, the overall aim was to increase 'financial transparency' surrounding party finances and donations to parties. (CNCCFP 1992, 9) Thirdly, in tandem with greater transparency, caps were introduced to place limits on the amount any one company or individual could contribute to any one candidate or party. Socialist aspirations in 1988 for tighter regulation, lower caps or even elimination of private financing (since this would hurt the Gaullists more than them) were not realised. In the end they abstained in the vote on the first (1988) law, in part over the minor issue of objecting to tax deductibility of donations.

Fourthly, business finance, which had hitherto been de jure illegal in France (although, de facto widespread), was legalised 1993, in a bid by 'realists' to bring 'occult' funding into the light. This despite strident opposition from Pierre Joxe, author of the 1990 law (1997). Fifthly, parties received (quite generous) public funding, which was scaled up as the reform process progressed - not only at election times, but also for running costs between elections. In the run up to passing the 1988 legislation, the Socialists complained vehemently that the state subsidies were being introduced in such a way as to disproportionately favour the RPR and UDF at the expense of the PS and others. The PC and FN voted against the 1988 law, and the PS abstained in part for this reason. ${ }^{6}$ However, these attempts to cartelise the French party system through manipulation of state subsidies system fell foul of French constitutional principles of equality, and the need to promote democratic pluralism in the expression of opinions and ideas. 
Rulings of the Constitutional Council, notably in January 1990, forced legislators make specific provisions (particularly in the 1995 legislation) to help small and emerging parties to ensure they did not ignore 'the demands of pluralism of ideas and opinions which constitutes the foundation of democracy'. Specifically, the Constitutional Council ruled the 5 per cent threshold which barred access of smaller parties to funding to be unconstitutional. ${ }^{7}$ Thus the guiding principles underpinning increasing state funding were the need to balance equality and proportionality - a desire for funding to reflect support for parties; balanced against a desire for 'fairness' to minor parties. This was rooted in the French model of multi-party liberal democracy. Political finance, it was felt, must be not only open and transparent, but 'fair' - in the sense of being subject to a cap and some financial 'affirmative action' preventing extreme inequalities of expenditure between parties. This provision had to grapple with the risk of abuse if thresholds for access to state funding dropped too low. Significantly, a later Constitutional Council decision explicitly stated that it had not ruled that thresholds themselves were unconstitutional, but only that the 5 per cent threshold had been too high. ${ }^{8}$

Between 1988 and 1995, the rationale underpinning the reforms process developed to plug gaps, close loopholes, in some cases to open loopholes, and tackle unforeseen consequences. Such insertion of loopholes and intentional laxity into the rolling programme of reform clearly illustrates a degree of 'strategic learning' by 'knowledgeable and reflexive [actors who] routinely (and often intuitively) monitor the consequences of their action' (Hay and Wincott 1998: 956). Impetus for further reform came from the political corruption scandals which emerged regularly, and received much media attention, throughout the period of reform. One key shift was to attempt to eradicate the link between private sector business interests and political parties and candidates by outlawing once more business funding in 
1995. Political finance should be, it was felt, free from business interests, and - in part as a corollary of this - underwritten by the state to a significant extent.

Former 'occult' funding networks channelled through local officials have by no means disappeared, and party funding scandals are still being uncovered and investigated (although most pertain to the period before 1995). ${ }^{9}$ Thus, to some extent, the spirit of unregulated party finance endures within the French regime. However, the powerful etatiste element within the French republican tradition now qualifies and counter-balances this, with the state financing on a significant scale and the requirement of parties to submit annual accounts.

[Table 1 About Here]

\section{Britain: Rationale for Reform}

Any discussion of reform in the areas of parties or indeed elections in Britain must take at least some account of the dominant so-called 'Westminster' model of democracy. Whilst constitutional changes in the post 1997 period (particularly with reference to devolution) have challenged this up to a point, it is fair to argue that this remains the dominant model. Thus, the basis upon which the party system is conceived implies a comfort with the principle of there being two dominant parties, with smaller parties being a feature of the system, but not one that is encouraged in any sense of affirmative action by the state. There are several striking examples of the continued dominance of these ideals. In the Jenkins review of alternative electoral systems there was a stated desire to avoid the 'coalition habit' (Margetts and Dunleavy, 1999). Moreover, in the subsequent proposed electoral system change in this review, and in the systems introduced for the devolved institutions of Scotland and Wales, the degree of proportionality introduced ensured that the party systems did not move too 
radically away from the Westminster norm. The two notable exceptions to this model have been the electoral systems introduced for the European elections and the Northern Ireland Assembly. In the latter, STV was used precisely to attempt to broaden the political perspective of the Assembly. In fact, the reverse happened following the 2003 elections. Nevertheless, despite these apparent anomalies, the Westminster model is arguably still dominant.

As we have seen, three other principles have traditionally characterised British political finance: campaign spending ceilings, voluntarism in party income and a general lack of regulation. Only the paucity of regulation has really changed in British party finance. Prior to the 2000 reforms, there were no limits on party income and reporting regulations were very limited. The latter has changed considerably. Yet whilst foreign donations have been banned and corporate donations now require prior shareholder approval, the tradition of uncapped donations remains. In that sense, the spirit of unregulated party finance endures.

Overall, these traditions shaped both the operations of political finance and attempts at its reform throughout the twentieth century. As Fisher (2000a) shows, despite the periodic examination from the 1970s onwards, what characterised previous attempts at reform was their failure to fundamentally change a system based largely upon nineteenth century regulation. And, though the 2000 Act represented a comparatively significant change, Clift and Fisher (2004) nevertheless demonstrate that their fingerprints can also be seen on the reform process itself, shaping the path of development. The reforms instigated and the previous positions are shown in Table 2 . These reforms were introduced for a variety of reasons, but principal reason was the disjuncture between optimal notions of behaviour and what actually occurred was growing (Clift and Fisher, 2004). 
Whilst no actual cases of corruption were proven, there were increasing concerns about the size and source of some donations, neither of which were regulated. Thus, whilst parties were behaving legally, the disjuncture between the 'logic of appropriateness' (March and Olsen 1984: 741; 1989: 21-6) of British party democracy and existing behaviour meant that the party funding regime was seen as illegitimate. In addition, there were other pressures, namely the increasing cost of politics and significant changes in the party finance community. There were changes in both the dominant sources of income as well as new actors offering newly legitimate inputs into debates about reform. The resulting reforms were all attempts to deal with these problems: transparency and a ban on foreign donations to address the suboptimal performance of the institution, and national spending caps to suppress the increasing costs and therefore the need to generate ever more income. In addition, the modest increase in state funding was an attempt to address the shortfall in parties' abilities to adequately fulfil their functions.

For all that, however, many of the existing traditions continued to shape the newly regulated institution. First, no attempt was made to challenge the dominant Westminster model. As Fisher (2001) shows, whilst the introduction of national campaign spending limits could have been seen as an attempt to narrow the spending disparity between the larger and smaller parties, the level was set at such a point that it barely made any difference. Secondly, the use of spending ceilings as an instrument to counteract apparent electoral inequality was a tried and tested policy instrument first utilised in the nineteenth century. Thirdly, the modest extension of state finance helped serve to maintain the existing dominant party system, whilst maintaining the traditions of voluntarism in British politics. State funding was rejected precisely because it was felt that parties should be funded primarily by their supporters. Only 
in the area of lack of regulation was there real change, though this stopped short of regulating the size of donations.

[Table 2 About Here]

Comparative analysis: Effectiveness and Unintended Consequences.

\section{France}

\section{Disclosure}

The National Commission on Campaign Accounts and Political Finance (CNCCFP) was established by the January 1990 Law to oversee the process of subjecting financial affairs of parties and elected officials to increased transparency and audit. The 1990 law tightened the 1988 disclosure restrictions, and these have proved partially effective. ${ }^{10}$ The legalisation and regulation of corporate funding in 1990 sought to change the norms, and the 'logic of appropriateness' underpinning French political finance. However, greater emphasis on transparency within the reform process has considerable limitations. The compulsion to publish accounts and name donors may do little to prevent a whole series of dubious practices that do not turn up on the balance sheet. ${ }^{11}$ Strategic learning by actors resulted in loophole seeking, which has undermined attempts to control donations from both individuals and firms. 'Personal' capital contributions by candidates to their own campaign (which are not subject to strict disclosure rules) increased fivefold between 1992 and 1995 (68 per cent of total receipts) (Doublet 1997b: 104). This loophole has the effect of blunting the transparency tool. $^{12}$ 
A still more debilitating limitation is article 4 of the 1958 Constitution, guaranteeing party freedom, preventing the Commission from investigating parties, or commenting on appropriateness of spending. The laissez faire strand of France's Republican tradition, has served to undermine the effectiveness of these dimensions of French political finance reform. Despite the best intentions of the CNCCFP to 'ensure the transparency of financial operations' of parties and candidates in electoral campaigns (CNCCFP 1992: 25), the wellestablished occlusion of French political finance proved too resilient. Thus the reform process has had the perverse unintended consequence of conferring a spurious air of legitimacy on political funding in France, ${ }^{13}$ since parties and candidates can point to the submission of their accounts and their campaign returns as evidence of having 'cleaned up their acts' - but Doublet goes so far as to describe the transparency as 'illusory' (1997b 104).

\section{Donations and Business funding}

As Table 1 shows, in 1988, donations to candidates (but not to parties) were limited. This loophole transformed parties into 'screens' to exceed ceilings on donations to candidates, contrary to spirit of law (CNCCFP 1992: 26-30). An ambiguity also remained surrounding party financing from companies (Miguet 1999: 58-9). The 1990 law $^{14}$ legalised (and regulated) business funding for the first time. Thereafter, parties encountered financial difficulties, indicating heavy prior reliance on business funding. As Knapp notes, the 1993 election campaign is instructive, as it was the only one where business funding was at least partially openly declared. ${ }^{15}$ Three quarters of declared corporate finance came from firms involved in bidding for public contracts, suggesting that, 'the brief emergence into legality of corporate donations merely drew back the veil on earlier illegal practices.'(2002: 125-6) 
However, in the wake of further scandals, the 1995 law made business funding illegal once more.

The design of the regime to regulate donations was, at times, shame-facedly self-serving. The CNCCFP had, in 1992, described the proliferation of 'groups of a political character, designed to promote a candidates personal image' and raise funds for their campaigns as 'against the spirit of the law' because they have 'the effect of circumventing the ceilings on donations' (CNCCFP 1992: 26). However, Prime Minister Balladur, whose 1995 presidential campaign suffered from a lack of party resources, since the Rassemblement Pour la République (RPR) was mobilized primarily behind Chirac, promoted an amendment enabling the creation of campaign support committees, similar to parties (and thus exempt from restrictions on donations to candidates). Balladur's campaign drew benefit from ninety-eight such 'American style' committees (Doublet 1999: 74).

Spending Ceilings and the Level Playing Field

The 1988 campaign ceilings included all 'tacitly' agreed spending on candidates' behalf, but not by them (Joxe 1997: 14). However, the phrase 'even tacit' was removed in December 1994, a move which, Joxe regretfully noted, 'was intended to render the ceiling inoperable' (1997: 14). With these 'tacit' expenses now falling outside the ceiling, the ceiling became ineffectual, as the Constitutional Council pointed out. ${ }^{16}$ Such insertion of loopholes and intentional laxity into the rolling programme of reform illustrates a degree of strategic learning. It also suggests that attempts to eradicate 'occult' funding ultimately failed. 
Underlying the imposition of a ceilings approach is a particular notion of a 'level playing field' between competing parties, presupposing some degree of equality. In France this logic is carried still further, through 'affirmative action' in the form of targeted state aid to help small and emerging political formations. Indeed, an initial threshold of 5 per cent for access to funding was ruled unconstitutional and abolished by the Constitutional Council. However, pre-existing norms of French political finance presented a significant obstacle to reform. Parties and candidates reliant upon 'occult' funding networks were unwilling, perhaps unable, to break out. These networks, and the circumventions of regulatory frameworks and spending ceilings, mean the level playing field remains more myth than reality.

\section{State Funding}

Perhaps the most radical element of the French reforms, marking a break with the laissez faire past, has been the introduction and augmentation of state funding of political parties. As noted above, the Constitutional Council intervened decisively to ensure the principles of equality and proportionality shaped the introduction of state funding. The Council's declared unconstitutionality of the 5 per cent threshold, and shift (also encouraged by the Constitutional Council) in eligibility from fielding candidates in 75 to 50 constituencies is evidence of the power of the French traditional of multi-party democracy as a normative institution guiding the reform process. When, in 1995 business funding was made illegal, parties and candidates received a compensatory increase in state funding. The amount of electoral expenses reimbursed increased from 5 per cent to 50 per cent of the ceiling on expenditure. Yet even with this increase in public funding, which totalled $526.5 \mathrm{~m} \mathrm{FF}$ (€80.38m) in 1997, still the parties could not balance their books. 
As noted above, Katz and Mair's 'Cartel Party' thesis interprets the augmenting of party funding as evidence of the advancing inter-penetration of party and state; 'the state ... becomes an institutionalised structure of support, sustaining insiders and excluding outsiders' (1995: 16). This all assumes effective control over the funding reform process by parties. However, such assumptions do not hold in the French case where the Constitutional Council intervened to rule the 5 per cent threshold unconstitutional. As a result, specific provision to foster the development of small, emerging political currents and movements, and the recognition of the need for 'affirmative action' in their favour, were integral to the French party finance reforms. Furthermore, predictions that cartelisation allows insider parties to minimise the costs of electoral defeat (Katz and Mair 1995: 23) have not been borne out in the French case. Powerful French insider parties such as the RPR and PS have been deeply adversely affected by electoral loss, forced into very severe spending cut-backs (Clift and Fisher 2004: 691 and 697).

Although the intentions of making sure small, or emerging political formations have a chance is honourable enough, the constitutional ruling that the 5 per cent threshold was too high opened the door to opportunism and abuse. The specific provisions to help emergent parties contained in the 1995 legislation were, in hindsight, perhaps not exigent enough. Testament to attempts at opportunistic exploitation of the generosity of the party funding regime in France, the number of political parties grew from 29 in 1990 to 261 (48 of which received some state funding) in 1995. Political finance legislation, the CNCCFP's third report noted, 'favours a multiplication of formation claiming the status of political parties, whilst their creation is sometimes motivated at least partially by the concern to benefit from direct financial aid.' (1996: 8; see also Doublet, 1997: 17 and 74; Miguet 1999: 72). 
Thus the most dramatic unintended consequences of the up-scaling of sate funding, and of the insertion of 'affirmative action' measures to empower smaller parties, has been to considerable exacerbate the fissiparous tendencies within a French party system which already unleashes powerful fragmentary pressures on parties. Parodi (1997) has noted that the candidate funding regime presents no barriers to minor parties or candidates, and acts to expand the number of candidates taking their place in the country's foremost political shop window. To borrow Parodi's analogy, the 'electoral accordion' was opened to the fullest extent ever seen in the Fifth Republic in 2002 Presidential election, with a record 16 first round candidates. The French political funding regime, Duhamel argues, 'transforms elections into financing mechanisms for political 'start-ups', when it is a not a case of personal enrichment by flash-in-the-pan leaders' (Duhamel 2002). The same structural incentives towards fragmentation as bedevil the presidential elections are present in legislative elections with regard to campaign funding. The parliamentary elections, which followed in June 2002, saw a record 8,446 first round candidates (up 32 per cent from 1997) - an average of 15 per constituency.

\section{Britain}

\section{Donations and Disclosure}

At the most basic level, the new Act introduced a degree of transparency into party donations that did not previously exist. However, far from transparency eliminating concerns about party finance, a series of problems clearly remain. First, both main parties continue to receive substantial donations - one of the concerns, which prompted legislation in the first place. Concerns about donations well in excess of $£ 1$ million $(€ 1,502,000)$ prior to the 2001 election, prompted the chair of the Electoral Commission to suggest that the question of donation caps might be re-examined in future just as the new legislation was coming into 
force. This duly occurred, with the Electoral Commission conducting an enquiry into this and other aspects of party finance in 2004.

Concerns also remain that preferential treatment has been given to donors. Four such episodes occurred in close succession during 2002 relating to Labour (Fisher, 2002). The Conservatives, too have experienced such questions in opposition (Fisher, 2004). In particular, the prominence of a major donor in debates about the party's leader in 2003 appeared to suggest that financial gifts lead to political influence. Yet, while these episodes do not necessarily suggest that impropriety has taken place, they all have the potential to damage public confidence - especially when as here, they appear in close succession and thereby create a cumulative effect. As then Leader of the House, Peter Hain noted, press attention generated by the transparency can, at times, degenerate into the bizarre, citing the headline 'Labour donor on speeding charge' (Hain, 2004: 14). So in a sense, the disclosure regulations may actually contribute to public disquiet. This clearly illustrates an unintended consequence of reform. By providing a wealth of new information in an attempt to allay public concern about probity in public life, the effect was in part at least to heighten the political sensitivity surrounding all donations. Paradoxically then, the transparency generated more concern rather than less, in part, because of the ways in which the media chose to report the newly available data.

\section{Spending Ceilings}

At the 2001 and 2005 General Elections, it is doubtful that the new spending caps made any decisive difference to party fortunes, especially as the spending gap between the main parties and the Liberal Democrats remained wide (Fisher, 2001, 2005). Instead, the principal impact was likely to have been one of changing the proportions spent on campaign items, rather than 
levelling the electoral playing field. The new limit imposes opportunity costs. If one million was spent on A, then that was one million that could not be spent on B or C. Thus, parties had to review their spending in order that it should be most effective. Interestingly, the two main parties do not always concur on which campaign techniques are regarded as being most likely to accomplish their aims. Nevertheless, this did indicate some strategic learning by the parties. They were forced to evaluate the efficacy of different campaign techniques.

\section{Compliance}

Compliance with the new legislation in the first post-legislation election (2001) inevitably caused a few problems given the extent of the new regulations. To some extent these difficulties were anticipated by the Act. One-off start-up grants were made available to assist parties in meeting the costs of compliance. Nevertheless, local parties did face a few problems - particularly with the heavier workload, which accompanied the changes to postal voting, and rolling registration. Despite these difficulties, parties adapted well to the new regulations, overall. There were some uncertainties, notably the status of some forms of donations 'in kind'. That said, the indications since then are that the regulations, both in spirit and actuality, have broadly been observed, though in the run-up to the 2005 election, there were some indications that the spirit of the legislation may have begun to be challenged, with the Conservative and Liberal Democrat parties apparently exploiting loopholes in reporting requirements. In both cases, whilst neither committed any breach of the legislation, they were in receipt of significant donations which on account of the point at which they were reported, ensured that their public declaration would occur after the election when the 'political moment' had passed (Fisher, 2005).

State funding - back on the agenda? 
Despite the new legislation, however, there continue to be concerns about the probity of party finance. Indeed, the regular appearance of these prompted some to call for further state funding - the expectation being that this would prevent such episodes. At the time of the original report by the Committee on Standards in Public Life in 1998, both the main parties concurred with the report's view that the time for state funding had not yet come. However, as a result of these episodes (and one suspects, the increased financial burden faced by parties following both general and devolved elections) both the Conservative and Labour parties now endorse an increase in the limited state funding, and in the case some senior Labour politicians, state funding comparable with other Western democracies. Critically however, neither Labour nor the Conservatives supports limiting the size of donations.

On the one hand, this is a clear example of the unintended consequences of reform. On the other, it in a way demonstrates strategic learning on behalf of the parties based in the new values engendered by reform. As we have seen, limited increases in state funding were introduced in recognition of the argument that parties were struggling to fulfil their principal functions. Whilst the tradition of voluntarism remains, it is arguable that the recognition of the importance of parties (explicit in the Neill Committee report which prompted the reforms) and the acknowledgement that the state can play an enhanced role in party finance has made it more acceptable for both parties to argue for enhanced provision. And, whilst neither principal party argued for comprehensive funding in the Electoral Commission's 2004 review, both agreed that an extension to cover some aspects of parties' work was desirable.

In this respect the unintended consequences of reform and parties' strategic learning is clear. The new regulations were supposed to negate the need for state funding. In fact, the new transparency in party finance declarations made calls for state funding even louder, both from 
within and outside parties. What is more, this led the Electoral Commission to re-examine the case for comprehensive state funding only two years after the original legislation had come into force. Parties have also demonstrated strategic learning. They have united around a theme of modest increases in state funding to facilitate particular party functions. This consensus did not exist prior to the extension of state funding post-Neill. Moreover, they have also both resisted calls to place caps on individual donations, noting that the success of actors like the Committee on Standards in Public Life and the Electoral Commission has been in part built on promoting reforms which have cross party support.

\section{Conclusions}

This article has highlighted the problems with assumptions underpinning party funding reform conceived as constitutional engineering along the lines of Katz and Mair's 'Cartel Party' thesis. Firstly, the assumed predictability of cause and effect has been found wanting in many instances. In both cases, the centrality of transparency to an optimal party funding regime has strongly influenced the reform process. The idea of a disjuncture between 'internal' values of institutions and 'external' values of wider society explains the impetus for funding reform in the context of sleaze and scandals. However, the aspirations in the French case have been unfulfilled. In France, the logic of appropriateness of actors within the system tended involve 'occult' funding sources. The resilience of pre-existing corrupt norms and networks of French political finance has led to intentional laxity and loophole-seeking, rendering the transparency illusory, and the ceilings and donations regulations largely inoperable. Given the failure to institute a robust transparency regime, the reform process has had the perverse unintended consequence of allowing parties to claim a spurious probity for 
their political funding given a highly visible and politically salient reform process, which has not eradicated the pre-existing dubious financial networks.

In Britain, as we have seen, there was the perverse outcome of more disquiet surrounding donations, post-transparency. However, just as French parties continued to be lax in terms of compliance, British parties followed the logic of appropriateness by largely complying with the new legislation - at least, at first. Fisher (2001) shows that parties were determined not to fall foul of the new regulations in the general election, and notwithstanding the cases prior to the 2005 election, there was no real evidence that the spirit of compliance has been in any way diluted. Equally, the Electoral Commission has been keen to ensure that it works with the parties, rather than against them to enhance compliance.

A second assumption that has proved difficult to sustain relates to the quality of information on which reform projects are based. Only more realistic assumptions about the necessary imperfection of the information can account for a range of often very significant unintended consequences of party funding reform unearthed in the comparative analysis presented here. The unintended consequences of reform in the French case served to exacerbate the problems of the fissiparous incentive structure of the French party system, leading to a proliferation of 'parties', some founded with the sole purpose of recouping generous state funding. In the British case, the move to introduce transparency as a means of quelling public disquiet about party finance, initially at least had the opposite effect. Fuelled by circumstantial speculation, the greater transparency led to early calls for more reform, both in terms of donation caps and enhanced state funding. Indeed, the Electoral Commission review of the act focussed heavily on these two aspects and it is arguable that the significant re-emergence of state funding onto 
the political agenda has been the major longer-term unintended consequence of the British reforms.

The third deviation from assumptions underpinning the Cartel Party ideal-type relates to the degree of control over the process exerted by parties. In both cases, this has been seen to be less than complete. Other actors, be they the Electoral Commission in Britain, or the Constitutional Council, have had decisive impacts of the paths of reform in both cases. These bodies have sought to enhance the democratic probity of party funding arrangements, but the 'optimal' notion of party democracy differs in the two cases. The French model of party democracy places more emphasis on multi-partyism, and as such contrasts with a Westminster Model more comfortable with two-party dominance. In relation to state funding, the policy corollary of this difference has been explicit 'affirmative action' to advance smaller parties within the French party system, whilst the British reform process has not seriously contemplated such measures. The Constitutional Council, in upholding the principle of multi-partyism, perhaps unwittingly increased fragmentation within the French party system. This has been the most significant unintended consequence of the French reforms.

One last note-worthy aspect of party funding reform processes under scrutiny here has been the reflexive relationship between agents and political funding structures. The French case showed two forms of 'strategic learning' by actors, on the one hand it took the form of loophole seeking (for example by channelling funds through 'personal' contributions to candidate's own campaigns, thus escaping donations and ceilings restrictions). On the other hand, agents succeeded in redesigning structures to increase room to manoeuvre after the strictest (1990) legislation proved too tight a constraint. Thus a degree of intentional laxity was re-introduced into the rolling reform programme through loophole insertion. Most 
conspicuous was the deleting of the 'even tacit' phrase from spending ceilings, rendering them largely inoperable, but also with the deliberate widening of the loophole permitting donations from parties to candidates in the 1993 legislation. In the British case, given the relative youth of the reforms, there have been fewer examples of strategic learning. Nevertheless, there has been some evidence in the readiness of the two major parties to more openly embrace targeted, but not comprehensive, state funding, made 'legitimate' by its inclusion in the original reforms. And in 2005, some parties arguably manipulated the timetable for declaring donations.

Overall, then, this analysis of party funding reform in France and Britain has demonstrated that constitutional engineering through party finance reform is a singularly inexact science, characterised by highly significant unintended consequences. These are largely due to the imperfect nature of information, the limited predictability of cause and effect, and the constraining influence of non-party actors, such as the Constitutional Council in France, and the Electoral Commission in Britain.

Word Count:. 7, 686

Date: 2 August, 2005. 
${ }^{1}$ Historically, no reliable data has been available regarding either French party membership levels or French party finances. This has made such claims impossible to verify

${ }^{2}$ Repercussions continued into the late 90s, and in 1997 Henri Emmanuelli, Treasurer of the Party at the time of URBA, received a suspended 18 month jail sentence, and was deprived of his droits civiques for 2 years.

${ }^{3}$ Indeed, Doublet argues that contributions of members represent only $8.3 \%$ of the global resources of parties (1999: 68). The combination of increased expenditure and declining revenues exacerbated concerns surrounding vested interests ability to 'buy' influence, for example over the allocation of public contracts, in return for the funds upon which parties are increasingly dependent.

${ }^{4}$ The office of the Socialist Defence Minister was accused of permitted unlawful exports of arms to Iran in contravention of an export ban in return for kickbacks to the party from the arms company.

${ }^{5}$ The former minister for co-operation who was tried for using the agency Carrefour du développement to divert large sums intended for African aid to fund his election campaigns. ${ }^{6}$ Le Monde 'L'adoption des projets de loi sur le financement de la vie politique. Les députés socialistes se réfugient dans l'abstention' 06 February 1988

${ }^{7}$ Conseil constitutionnel, Décision n 89-271 DC, 11 January 1990. 'Loi relative à la limitation des dépenses électorales et à la clarification du financement des activité politique' http://www.conseil-constitutionnel.fr/decision/1989/89271dc.htm

Accessed 11 May 2005. Author's translation.

${ }^{8}$ Conseil constitutionnel, Décision du 29 mars 1994 'Observations du Conseil constitutionnel relatives aux élections législatives des 21 et 28 mars 1993' http://www.conseilconstitutionnel.fr/decision/1994/940329.htm Accessed 11 May 2005.

${ }^{9}$ One high profile example, centring on former Minister Michel Roussin, involves payments from companies bidding for school maintenance and building contracts in Ile-deFrance to the RPR between 1990 and 1995. See, for example, 'La collusion des patrons, au procès des marchés d'Ile-de-France', Le Monde, 23 April 2005.

10 For example, when business funding was again outlawed in 1995 (see below), the finances of the RPR in particular sustained a significant blow, suggesting, in the more transparent climate, not all their previous business donations found their way into the coffers by a more circuitous route. A further consideration may have been the record of the RPR Governments of the mid 1990s.

11 For example, companies letting office space to parties at below market rates, or buying advertising space at inflated prices. Furthermore, cash contributions may go unrecorded, as may use of a company's assets - 
cars, computers, phones and the like, during a campaign. Furthermore, of course, illegal donors will not be issued with a receipt.

12 Nor is it an isolated example. As far as party transparency goes, there is no systematic tracing of the local activities of parties. Between 1990 and 1995, French party accounts often conflated individual and corporate donations - leaving the commission unable to ensure observance of ceilings.

13

There is evidence that the measures taken have not really enhanced the legitimacy of French political finance in the eyes of the French electorate. A study published in Le Monde in 2000 found that only 33 per cent of respondents felt there had been 'some cleaning up of the financing of politics'. Regarding the effectiveness of spending ceilings and the outlawing of business funding, 62 per cent felt that there had 'not really been any change'. Le Monde 'Scepticisme sur le financement des partis politiques', 05 October 2000.

14 The most rigorous and stringent package passed in the 'legislative incontinence' of the late 1980s and 1990s

- which were subsequently 'loosened' in key respects.

In 1992, Prime Minister Bérégovoy declared his intention of ‘draining the abscess of corruption'. He wanted to cut ties between business and politics, but failed due to widespread opposition. Instead, business donations capped at one quarter of resources spent by the party in the previous election. Disclosure requirements were strengthened, parties and candidates required to publish an 'exhaustive' list of donor companies. However, the 1993 Sapin law was circumvented by large companies with lots of subsidiaries.

${ }^{16}$ Conseil constitutionnel, Décision du 11 octobre 1995 'Décision du Conseil constitutionnel relative au compte de campagne de Monsieur Jacques Chirac, candidat à l'élection présidentielle des 23 avril et 7 mai $1995^{\prime}$ http://www.conseilconstitutionnel.fr/decision/1995/9525.htm accessed 11 May 2005. 
Table 1

\section{French Party Finance Regulation Pre and Post reform}

\begin{tabular}{|c|c|c|}
\hline & Pre- 1988 (beginning of reform process) & After the 1988-95 reform process \\
\hline Donations & $\begin{array}{l}\text { - No caps on donations by individuals } \\
\text { - Donations from companies de jure illegal for both giver and } \\
\text { recipient, but de facto widespread. }\end{array}$ & $\begin{array}{l}\text { 1988 Law - Tax relief on donations to candidates, limited to } \\
\text { 20,000ff }(€ 3,049) \text { by individuals, } 50,000 \mathrm{ff}(€ 7,622) \text { by } \\
\text { organisations. } \\
\text { - } \\
\text { Donations over } 2,000 \mathrm{ff}(€ 305) \text { had to be by cheque, and cash } \\
\text { cannot exceed } 20 \% \text { total funding. } \\
\text { - } \text { Ambiguity over legality of corporate donations to parties. } \\
1990 \text { Law - Corporate donations legalised. Ceilings on both } \\
\text { individual and corporate donations - Parties were entitled to } \\
\text { receive 50,000ff ( } € 7,622) \text { from individuals, and 500,000ff ( } € \\
\text { 76, 225) from corporate bodies per year. } \\
\text { - Donations from parties to candidates not regulated. This major } \\
\text { loophole was deliberately widened in the } 1993 \text { legislation. } \\
\text { 1995 - Corporate donations made illegal once more }\end{array}$ \\
\hline $\begin{array}{l}\text { Disclosure \& } \\
\text { Transparency }\end{array}$ & $\begin{array}{l}\text { - No infrastructure to ensure transparency } \\
\text { - No disclosure requirements for individuals } \\
\text { - } \quad \text { No disclosure requirements for parties }\end{array}$ & $\begin{array}{l}\text { - Detailed annual accounts and donations declared to new } \\
\text { National Commission on Campaign Accounts and Political } \\
\text { Finance (CNCCFP) and published. Compelled revealing the } \\
\text { identity of donors. } \\
\text { - Declaration of 'tacit' donations introduced in } 1990 \text { to tackle } \\
\text { loopholes of } 1988 \text { act } \\
\text { - 'Tacit' donations subsequently excluded in } 1994\end{array}$ \\
\hline Foreign Donations & - $\quad$ Foreign Donations Legal & - $\quad$ Foreign donations banned in 1988 \\
\hline $\begin{array}{l}\text { Campaign } \\
\text { Spending Ceilings }\end{array}$ & - No campaign spending ceilings & $\begin{array}{l}\text { 1988 Law - spending ceilings established for legislative - } \\
\text { 500,000ff }(€ 76,225) \text { per candidate and presidential }(120 \mathrm{~m} \text { ff } \\
\text { [E18.3m], rising to } 140 \mathrm{~m}[€ 21.3 \mathrm{~m}] \text { in the second ballot) } \\
\text { elections. Campaign defined as } 3 \text { months before election } \\
\text { - } 1990 \mathrm{Law} \text { - campaign period extended to one year. Raised } 2^{\text {nd }} \\
\text { round presidential ceiling to } 160 \mathrm{~m} \mathrm{ff} \text {. } \\
\text { 1993 Law - Assemblée nationale ceilings revised }(500,000 \mathrm{ff} \\
>250,000 \mathrm{ff}[€ 76,225>38,112] \text { per candidate plus } 1 \mathrm{ff}\end{array}$ \\
\hline
\end{tabular}




\begin{tabular}{|c|c|c|}
\hline & & [€E0.15] per inhabitant - average total 350,000ff [€53,357]) \\
\hline
\end{tabular}


Table 2

British Party Finance Regulation Pre and Post 2000

\begin{tabular}{|c|c|c|}
\hline & Pre- 2000 & Post 2000 Changes \\
\hline Donations & $\begin{array}{l}\text { - } \\
\text { - } \\
\text { Trade limits on donations size } \\
\text { continuation of political fund (from which party } \\
\text { affiliation is paid) every ten years since } 1984\end{array}$ & $\begin{array}{l}\text { Shareholders to be balloted prior to corporate } \\
\text { donations being made. }\end{array}$ \\
\hline Disclosure \& Transparency & $\begin{array}{l}\text { Legal requirement on disclosure for companies } \\
\text { and trade unions } \\
\text { - No disclosure requirements for individuals } \\
\text { - No disclosure requirements for parties }\end{array}$ & 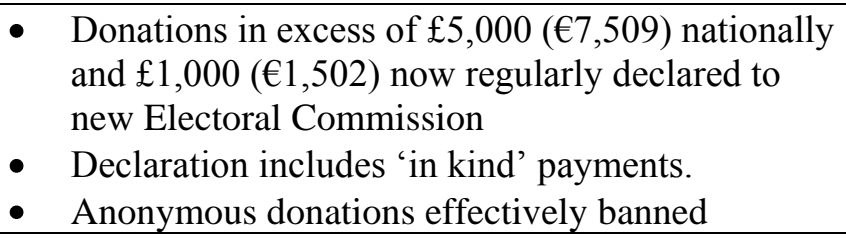 \\
\hline Foreign Donations & - $\quad$ Foreign donations permitted & - $\quad$ Foreign Donations banned \\
\hline Campaign Spending Ceilings & 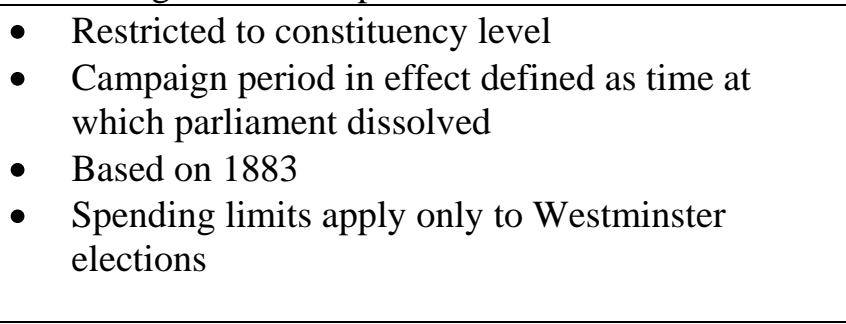 & $\begin{array}{l}\text { - National campaign spending limits set }(£ 30,000 \\
{[€ 45,051] \text { per contested constituency) - }} \\
\text { previously only constituency limits } \\
\text { - } \quad \text { Campaign period defined as } 365 \text { days before } \\
\text { election } \\
\text { - Spending limits for Westminster and non- } \\
\text { Westminster elections }\end{array}$ \\
\hline State Funding & $\begin{array}{l}\text { - Limited financial support for opposition parties in } \\
\text { parliament ('Short' money) since } 1975 \\
\text { - All other state aid is 'in kind' }\end{array}$ & $\begin{array}{l}\text { - Limited increase in state funding - remains } \\
\text { modest in comparison } \\
\text { - Increase in parliamentary support ('Short' money) } \\
\text { - Establishment of Policy Development Fund }\end{array}$ \\
\hline
\end{tabular}




\section{References}

Avril, P. (1994) 'Regulation of Political Finance in France' in H. Alexander and R. Shiratori (eds) Comparative political finance among the democracies Boulder: Westview Press.

Clift, B. (2005) 'Dyarchic Presidentialization in a Presidentialized Polity: The French Fifth Republic' in P. Webb and T. Poguntke (eds.) The Presidentialization of Politics: A comparative Study of Modern democracies (Oxford University Press), pp 219-243.

Clift, B. and Fisher, J. (2004) 'Comparative Party Finance Reform: The Cases of France and Britain' Party Politics 10(6): 677-699.

Commission Nationale Des Comptes de Campagne et des Financement Politiques (1992) Premiere Rapport Paris: La Documentation Française.

Commission Nationale Des Comptes de Campagne et des Financement Politiques (1996) Troisième Rapport Paris: La Documentation Française.

Doublet, Y (1999) 'Party Funding in France', in Ewing K.D. (ed) The Funding of Political Parties: Europe and Beyond Bologna: Cooperativa Libraria Universitaria Editrice Bologna.

Doublet, Y. (1997a) Le Financement de la Vie Politique Paris: Presses Universitaires de France.

Doublet, Y. (1997b) 'La réglementation du financement de la vie politique est-elle souhaitable, est-elle possible?', Revue Française des Finances Publiques 58: 101-114.

Duhamel, O. (2002) 'L’implosion Présidentielle', Le Monde, 20 April.

Fisher, J. (1992) 'Trade union political funds and the Labour Party', in P. Norris et al (eds) British Elections and Parties Yearbook 1992 Hemel Hempstead: Harvester Wheatsheaf 
Fisher, J. (1994a), Political Donations to the Conservative Party', Parliamentary Affairs 47: $61-72$

Fisher, J. (1997), 'Donations to Political Parties', Parliamentary Affairs 50:235-45.

Fisher, J. (1999) 'Party expenditure and electoral prospects: a national level analysis of Britain', Electoral Studies 18(4): 519-32.

Fisher, J. (2000a) 'Party Finance and Corruption: Britain', in Robert Williams (ed) Party Finance and Political Corruption, Basingstoke: Macmillan Press, pp. 15-36.

Fisher, J. (2000b) 'Economic performance or electoral necessity? Evaluating the system of voluntary income to political parties', British Journal of Politics and International Relations 2 (2): 179-204.

Fisher, J. (2001) 'Campaign Finance: Elections Under New Rules', in Norris, P. (ed) Britain Votes 2001 Oxford: Oxford University Press

Fisher, J. (2002) 'Next Step: State Funding for the Parties?' Political Quarterly 73(4): 392-9.

Fisher, J. (2004) 'Money matters: the financing of the Conservative Party' Political Quarterly 75(4): 405-10

Fisher, J. (2005) 'Campaign Finance' in Geddes, A., and Tonge, J., Title to Be Confirmed: The British General Election of 2005 Basingstoke: Palgrave.

Hain, P. (2004) 'Come to the aid of the party' Fabian Review 116(1) 13-4.

Hay, C. and Wincott, D. (1998) ‘Structure, Agency and Historical Institutionalism’ Political Studies, 46(5): 951-957.

Hazareesingh, S. (1994) Political Traditions in Modern France Oxford: Oxford University Press.

Hopkin, J. (2004) 'The Problem with Party Finance: Theoretical Perspectives on the Funding of Political Parties' Party Politics, 10(6): 627-51

Joxe, P. (1997) 'Le financement des partis politiques', Revue Française des Finances Publiques 58: 11-19. 
Katz, R. and Mair, P. (1995) 'Changing Models of Party Organization and Party Democracy: The Emergence of the Cartel Party' Party Politics 1( 1): 5-28.

Knapp, A. (2002) 'France: Never a Golden Age' in P. Webb, I. Halliday and D. Farrell (eds) Political Parties in Advance Industrial Democracies, Oxford: Oxford University Press, pp. 107-150.

March, J. G. and Olsen, J. P. (1984) 'The New Institutionalism: Organizational Factors in Political Life’ American Political Science Review 78(3):734-749.

March, J.G. and Olsen, J.P. (1989) Rediscovering Institutions New York: Free Press.

Margetts, H. and Dunleavy, P. (1999) 'Reforming the Westminster Electoral System: Evaluating the Jenkins Commission Proposals’ British Elections and Parties Review 9: 46-71

Miguet, A. (1999) 'Funding of Political Life in the Fifth Republic', in Ewing K.D. (ed) The Funding of Political Parties: Europe and Beyond Bologna: Cooperativa Libraria Universitaria Editrice Bologna.

Parodi, J-L. (1997) 'Proportionnalisation, périodique, cohabitation, atomisation patisane: un triple défi pour le régime semi-presidentiel de la Cinquième République?' Revue Française de science politique, 47(3-4): 292-312.

Peters, B. Guy (1999) Institutional Theory in Political Science London: Continuum.

Pierre, J., Svåsand, L. and Widfeldt, A. (2000) 'State Subsidies to Political Parties: Confronting Rhetoric with Reality', West European Politics 23 (3): 1-24.

Pinto-Duschinsky, M. (1981) British Political Finance 1830-1980 Washington: American Enterprise Institute.

Przeworski, A. and Teune, H. (1970) The Logic of Comparative Social Inquiry New York: Wiley.

Pujas, V. and Rhodes, M. (1999) 'Party Finance and Political Scandal in Italy, Spain and' West European Politics, 22(3) 41-63. 
Sartori, G. (1997) Comparative Constitutional Engineering Basingstoke: Macmillan.

Scarrow, S. (2004) 'Explaining Party Finance Reforms: Competition and Context' Party Politics 10(6) 653-75

Taagepara, R. and Shugart, M. (1989) Seats and Votes: The Effects and Determinants of Electoral Systems New Haven: Yale University Press.

Thelen, K. and Steinmo, S. (1992) 'Historical institutionalism in comparative politics' in S. Steinmo, K. Thelen and F. Longstreth (eds) Structuring Politics, Cambridge: Cambridge University Press, pp. 1-32.

van Biezen, I. (2004) ‘Political Parties as Public Utilities’ Party Politics 10(6): 701-22. 